\title{
Funding the new biologics - What can we learn from infliximab? The CCOHTA report: A gastroenterologist's viewpoint
}

\author{
Robert Hilsden MD PhD FRCPC
}

\begin{abstract}
R Hilsden. Funding the new biologics: What can we learn from infliximab? The CCOHTA report: A gastroenterologist's viewpoint. Can J Gastroenterol 2002;16(12):865-868
\end{abstract}

The treatment of severe Crohn's disease is difficult, and approximately $20 \%$ of patients do not respond to conventional therapy, including corticosteroids and immunosuppressives. Infliximab is one of the only treatments of proven efficacy in this group. Awareness of its benefits and risks is incomplete, because the drug has only recently been introduced and published research data are relatively sparse. Economic analyses help to evaluate the value of interventions that are both effective and expensive, but their validity is compromised by input data that involve questionable assumptions. They should not, therefore, be the only basis for funding decisions. Patients with severe Crohn's disease are frequently unable to be gainfully employed and thus incur significant indirect costs. In a recent study by the Canadian Coordinating Office for Health Technology Assessment (CCOHTA), infliximab was deemed to not meet commonly accepted standards of cost effectiveness. This economic analysis did not incorporate indirect costs, and thus was inherently flawed and likely underestimated infliximab's value. The CCOHTA report also used population data from a period of time during which treatment of Crohn's disease was undergoing major transition. The study population was based in Minnesota and thus might not be applicable to Canada. Although they are routinely used in cost effectiveness models, quality-adjusted life-years gained are difficult to translate into practice, and the health care resources required to induce remission (or some other clinically meaningful result) might be a preferable measure. The CCOHTA report also did not include concomitant therapy with immunosuppressives, despite growing evidence for its benefit. Instead, it considered 'usual care', but, given the lack of effective treatment for many patients with Crohn's disease, such an option constitutes 'no care' and continued suffering. Economic analyses should not be the only basis on which decisions regarding the funding of infliximab, or other new agents, are made.

Key Words: CCOHTA; Epidemiology; Infliximab

\section{Le financement de nouveaux produits} biologiques : que pouvons-nous apprendre de l'infliximab? Rapport de l'OCCETS : le point de vue d'un gastro-entérologue

RÉSUMÉ : Le traitement des formes graves de la maladie de Crohn s'avère difficile, et environ $20 \%$ des patients se montrent réfractaires au traitement usuel, y compris aux corticostéroïdes et aux immunodépresseurs. L'infliximab est l'un des seuls traitements à avoir prouvé son efficacité chez ces patients. On n'en connait pas encore très bien les bienfaits et les risques étant donné qu'il s'agit d'un médicament nouveau et qu'il existe peu de données de recherche publiées sur la question. Les analyses économiques aident à apprécier la valeur des interventions qui sont à la fois efficaces et coûteuses, mais des données d'entrée liées à des hypothèses douteuses entachent leur validité. Aussi ces analyses ne devraient-elles pas servir de seul fondement aux décisions relatives au financement. Souvent, les patients souffrant d'une forme grave de la maladie de Crohn ne peuvent exercer un emploi rémunérateur et, de ce fait, supportent des

suite à la page suivante

Presented at a workshop held at the University of Calgary, September 24, 2002. The workshop was supported by an unrestricted grant from Schering Pharmaceuticals, Pointe-Claire, Quebec

Departments of Medicine and Community Health Sciences, University of Calgary, Calgary, Alberta

Correspondence: Dr R Hilsden, 3330 Hospital Drive Northwest, Calgary, Alberta T2N 4N1. Telephone 403-210-9355, fax 403-220-8747, e-mail rhilsden@ucalgary.ca 
coûts indirects fort élevés. Dans une étude récente, l'Office canadien de coordination de l'évaluation des technologies de la santé (OCCETS) jugeait que l'infliximab ne satisfaisait pas aux normes généralement reconnues de rentabilité. Toutefois, l'étude ne tenait pas compte des coûts indirects; elle était donc viciée au départ et elle a proba-blement sousestimé la valeur de l'infliximab. De plus, le rapport de l'OCCETS repose sur des données démographiques recueillies à une époque où le traitement de la maladie de Crohn traversait une période de grande transition. En outre, la population à l'étude vivait au Minnesota; elle pourrait donc ne pas être un juste reflet de la population au Canada. Par ailleurs, même si elles sont souvent intégrées dans les modèles d'analyse coût-efficacité, les années-personnes sans invalidité gagnées sont difficiles à mesurer con- crètement dans la pratique, et le calcul des ressources en soins de santé nécessaires pour susciter une rémission (ou quelque autre résultat significatif sur le plan clinique) pourrait s'avérer une mesure plus juste. Le rapport de l'OCCETS n'a pas tenu compte non plus de la thérapie concomitante aux immunodépresseurs, malgré ses bienfaits de plus en plus reconnus. Au contraire, on s'en est tenu aux « soins usuels » mais, compte tenu de l'inexistence de traitement efficace chez bon nombre de patients atteints de la maladie de Crohn, ce genre de décision équivaut à une conduite abstentionniste et à la persistance du mal. Somme toute, les analyses économiques ne devraient pas être le seul élément justifiant les décisions relatives au financement de l'infliximab, ou de tout autre médicament nouveau.
Tnfliximab is one of the few promising therapies developed for Crohn's disease that has withstood the rigors of randomized controlled trials (1-4). It has been approved in Canada and the United States for the treatment of Crohn's disease refractory to conventional treatment and for fistulous disease. Our knowledge about the effectiveness and safety of infliximab is still incomplete because only a small number of trials have been performed, and it has only recently been introduced into clinical practice $(5,6)$.

As a practising physician, I base my decision to use a particular therapy on several factors: the severity of the condition, the efficacy of the therapy in clinical trials, how effective the therapy has been in my own experience, and the frequency and severity of side effects. In addition, economic models can be very valuable to the practising physician because they provide a 'bang for the buck' estimate for new interventions. They are frequently used by policy makers when deciding whether to fund a new therapy or intervention.

If we knew how effective an intervention is and what it would cost in the real world, we would not need an economic model. An economic model uses the best available evidence to provide an estimate of the cost effectiveness of a new therapy, which is expressed as a ratio of the costs to some measure of benefit. When uncertainty exists about the costs and benefits of alternative strategies, the validity of the model outputs is critically dependent on the inputs, many of which might be of dubious validity.

An inherent danger with economic models is that they are used as the sole criterion on which funding decisions are made. Just as I believe it would be incorrect to base treatment decisions purely on one criterion, such as efficacy of a treatment, so do I believe that it would be inappropriate to base funding decisions purely on an economic model.

This paper discusses the March 2002 report published by the Canadian Coordinating Office for Health Technology Assessment (CCOHTA) entitled Infliximab for the Treatment of Crohn's Disease (7). The authors of the report addressed the use of infliximab for refractory inflammatory Crohn's disease, by creating an economic model from a Ministry of Health perspective. The findings of the report indicate that the cost utility of infliximab does not meet accepted standards. The economic model described in the report was rigorously created using the best available evidence, although the authors recognized its limitations. I will argue that, in this case, the best is not good enough and leads to unjustified denial of funding for infliximab by the Ministry of Health and third-party payers.

\section{SEVERE CROHN'S DISEASE IN PERSPECTIVE}

It is important to put the disease and its treatment into perspective. Approximately 20\% of patients do not respond to conventional medical therapies, mainly corticosteroids and immunomodulators $(8,9)$. These patients have chronically active symptoms that require ongoing medication use, admission to hospital or even surgery, resulting in high direct medical costs $(10,11)$.

Patients with moderately to severely active Crohn's disease also incur high indirect costs, because they are often chronically disabled and unable to work. For example, our group recently conducted a national survey of patients with Crohn's disease who belong to the Crohn's and Colitis Foundation of Canada. We found that $40 \%$ of those who reported their disease to be severe, but only $13 \%$ of those with inactive or mild disease, were not in full- or part-time employment, enrolled as a student or working as a homemaker. A total household income of less than $\$ 20,000$ was reported by $11 \%$ of patients with severe disease compared with only $3 \%$ of those with inactive disease. A Swedish study suggested that the indirect costs of Crohn's disease were twice that of the direct costs (12).

\section{CCOHTA REPORT}

The economic analysis undertaken by CCOHTA was a cost utility analysis from a Ministry of Health perspective using only direct medical costs. Four treatment scenarios were evaluated for the treatment of refractory Crohn's disease: (1) usual care; (2) infliximab single infusion $5 \mathrm{mg} / \mathrm{kg}$; (3) infliximab single dose then retreatment as needed; and (4) infliximab single dose and then maintenance dosing every eight weeks. Health state transition data were obtained from a 1970-1993 cohort of patients from Olmsted County, Minnesota (13). Utility values were obtained from a single Canadian study (14). Sensitivity analyses demonstrated the robustness of the findings.

The results of the CCOHTA analysis were that usual care (defined as conventional medical and surgical therapy) 
incurred a cost of $\$ 9941$ per 0.6281 quality-adjusted lifeyear gained (QALY), and that each infliximab strategy was associated with an additional cost beyond that of usual care. In fact, a single dose of infliximab was associated with an incremental cost-utility ratio (ICUR) of $\$ 181,201$, the use of repeated doses as required had an ICUR of $\$ 480,111$, and maintenance therapy had an ICUR of $\$ 696,078$. These values for infliximab therapy are all higher than the often quoted but arbitrary threshold values of cost effectiveness, such as $\$ 100,000$ per QALY.

All economic models are subject to limitations, because they attempt to model reality using incomplete data. From my perspective as a gastroenterologist, the major limitations of the CCOHTA model are as follows: (1) the use of a historical American patient cohort to define health state transitions that may not be representative of Canadians in 2002; (2) inclusion of only direct costs for a disease with significant indirect costs; and ( 3 ) the use of QALYs.

Economic models require estimates of the probability that a hypothetical patient will move from one health state to another in the absence of the intervention of interest. The only estimates available to the authors of the report were from a cohort of patients residing in Olmsted County, Minnesota, who were followed from 1970 to 1993. This period was one of dynamic change in the management of Crohn's disease. It saw the publication of the National Cooperative Crohn's Disease Trial, the first large trial to document the effectiveness of corticosteroids and azathioprine. Throughout this time, physicians increasingly prescribed azathioprine as they became more comfortable with the agent and less concerned with long term side effects. In addition, there were changes in attitudes toward surgery and the use of parenteral nutrition and corticosteroids. Finally, methotrexate had not yet been shown in randomized controlled trials to be effective in the induction and maintenance of remission. Therefore, I do not believe that this American cohort, surrounding a tertiary referral centre, could, with great confidence, be used to model the disease trajectory of contemporary Canadians with Crohn's disease. Specifically, the usual medical therapy during the time of the Mayo Clinic study (13) included sulfasalazine, systemic corticosteroids and antibiotics. The new 5 -aminosalicylic acid agents were just being introduced at that time, the use of azathioprine and 6-mercaptopurine was not yet routine, and other immunosuppressive agents were not available.

As previously mentioned, patients with chronically active Crohn's disease can incur significant indirect costs. Therefore, I believe that any economic model that does not consider these is inherently flawed.

The use of QALYs is routine in modern economic analyses. They attempt to incorporate quality of life and patient preferences for a given health state into measurements of treatment outcomes. When applied uniformly, they allow comparisons of interventions both within diseases and across diseases, so that decisions might be made about the allocation of limited resources. Although I can define a QALY and produce the formula for calculating it, I find it very to difficult to provide a meaningful, patient-based interpretation of it. What does $\$ 181,000$ per QALY mean to the patient sitting across from me in the clinic?

I think it would be of much greater value to provide an estimate of the costs to achieve a clinically meaningful outcome, such as clinical response or remission. When publishing the results of epidemiological studies or clinical trials, we always attempt to translate the results into readily interpretable parameters, such as the population-attributable risk or the number needed to treat, which can be readily understood by persons without specific expertise in the underlying methodology. An estimate of cost per remission is much more relevant to physicians and patients, and would not preclude a simultaneous calculation of cost per QALY output. Before considering the economic impact, as defined by cost per QALY, of a therapeutic intervention, I think we must consider its value to the individual patient.

Concomitant use of immunosuppressives might both improve outcomes and reduce costs if it resulted in successful treatment with fewer infliximab infusions, but the optimal therapeutic regimen has not been defined. Optimal use of immunosuppressive drugs was not included in the model constructed by the CCOHTA authors. For example, the combination of infliximab and azathioprine, 6-mercaptopurine or methotrexate was not available as a therapeutic option, even though recent data suggest that it might be particularly valuable.

Finally, we must recognize that, for some patients, no good alternative therapy exists. For these patients 'usual care' means no care with ongoing suffering.

\section{CONCLUSION}

The authors of the CCOHTA report have created a rigorous economic model, using the best available data. The authors acknowledge in the report most of the limitations that I have discussed. The report provides valuable information, but it should not be the only analysis upon which funding decisions for infliximab are based. It is clear that biological agents will be of key importance in the future treatment of Crohn's disease and that they will all be expensive. It is important that we have the necessary tools, including economic models, to properly evaluate them. I believe that further studies are required to promote the validity of economic models. This research would include longitudinal studies to better define patient subgroups and their disease trajectory, and trials of concomitant immunosuppressives and infliximab. Cost-of-illness studies should include the assessment of indirect costs. We must also clarify the efficacy of infliximab in achieving and maintaining remission in well-defined patient groups. The failure to provide new therapies of proven efficacy for patients with severe Crohn's disease has significant clinical repercussions and should not be based on economic analyses that are constructed from tenuous data. Infliximab is of proven efficacy in patients with refractory or fistulizing Crohn's disease. Its availability should not be withheld on the basis of economic analyses that are based on tenuous assumptions and calculations. 


\section{REFERENCES}

1. Targan SR, Hanauer SB, van Deventer SJ, et al. A short-term study of chimeric monoclonal antibody cA2 to tumor necrosis factor alpha for Crohn's disease. Crohn's Disease cA2 Study Group. N Engl J Med 1997;337:1029-35.

2. Present $\mathrm{DH}$, Rutgeerts $\mathrm{P}$, Targan $\mathrm{S}$, et al. Infliximab for the treatment of fistulas in patients with Crohn's disease. N Engl J Med 1999;340:1398-405.

3. Rutgeerts P, D'Haens G, Targan S, et al. Efficacy and safety of retreatment with anti-tumor necrosis factor antibody (infliximab) to maintain remission in Crohn's disease. Gastroenterology 1999;117:761-9.

4. Hanauer SB, Feagan BG, Lichtenstein GR, et al. Maintenance infliximab for Crohn's disease: the ACCENT I randomised trial. Lancet 2002;359:1541-9.

5. Sample C, Bailey RJ, Todoruk D, et al. Clinical experience with infliximab for Crohn's disease: The first 100 patients in Edmonton, Alberta. Can J Gastroenterol 2002;16:165-70.

6. Rubenstein JH, Chong RY, Cohen RD. Infliximab decreases resource use among patients with Crohn's disease. J Clin Gastroenterol 2002;335:151-6.

7. Marshall JK, Blackhouse G, Goeree R, et al. Infliximab for the treatment of Crohn's disease: A systematic review and cost-utility analysis. Technology report no 24, 2 A.D. Ottawa: Canadian
Coordinating Office for Health Technology Assessment (CCOHTA)s, 2002.

8. Munkholm P, Langholz E, Davidsen M, Binder V. Frequency of glucocorticoid resistance and dependency in Crohn's disease. Gut 1994:35:360-2.

9. Munkholm P, Langholz E, Davidsen M, Binder V. Disease activity courses in a regional cohort of Crohn's disease patients. Scand J Gastroenterol 1995;30:699-706.

10. Bernstein CN, Papineau N, Zajaczkowski J, Rawsthorne P, Okrusko G, Blanchard JF. Direct hospital costs for patients with inflammatory bowel disease in a Canadian tertiary care university hospital. Am J Gastroenterol 2000;95:677-83.

11. Metge CJ, Blanchard JF, Peterson S, Bernstein CN. Use of pharmaceuticals by inflammatory bowel disease patients: A population-based study. Am J Gastroenterol 2001;96:3348-55.

12. Blomqvist P, Ekbom A. Inflammatory bowel diseases: Health care and costs in Sweden in 1994. Scand J Gastroenterol 1997;32:1134-9.

13. Silverstein MD, Loftus EV, Sandborn WJ, et al. Clinical course and costs of care for Crohn's disease: Markov model analysis of a population-based cohort. Gastroenterology 1999;117:49-57.

14. Gregor JC, McDonald JWD, Klar N, et al. An evaluation of utility measurement in Crohn's disease. Inflamm Bowel Dis 1997;3:265-7 


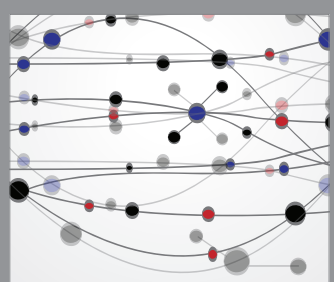

The Scientific World Journal
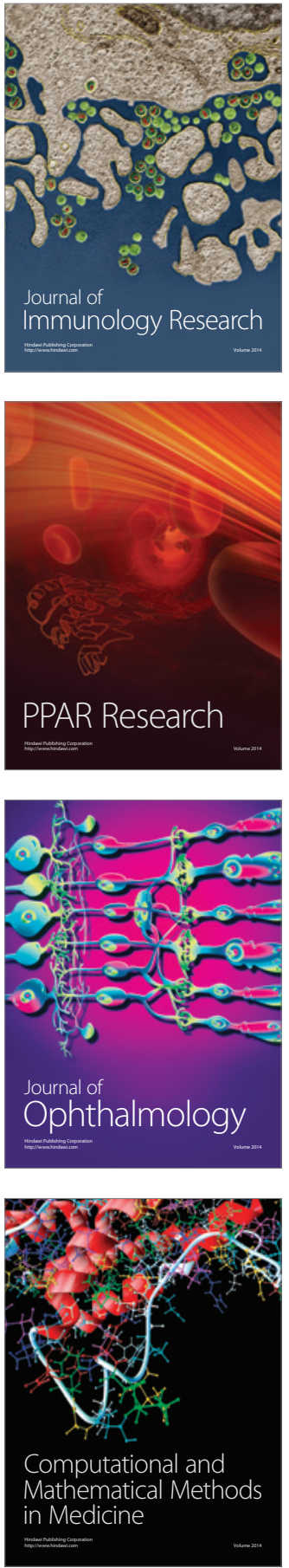

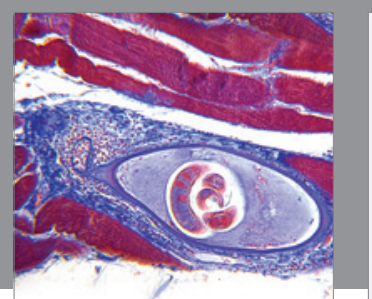

Gastroenterology Research and Practice

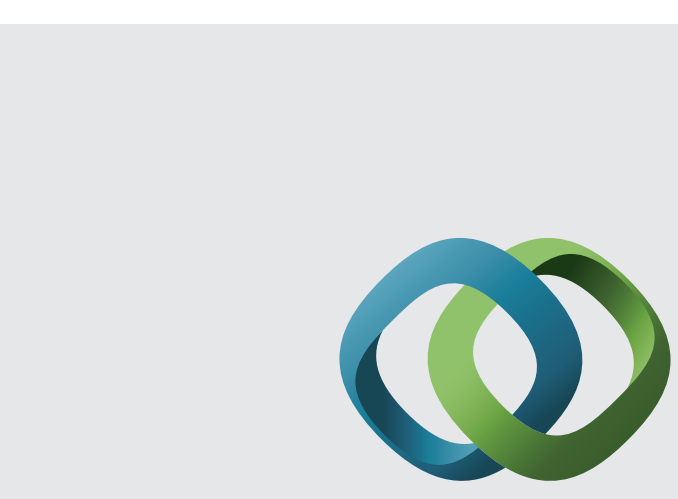

\section{Hindawi}

Submit your manuscripts at

http://www.hindawi.com
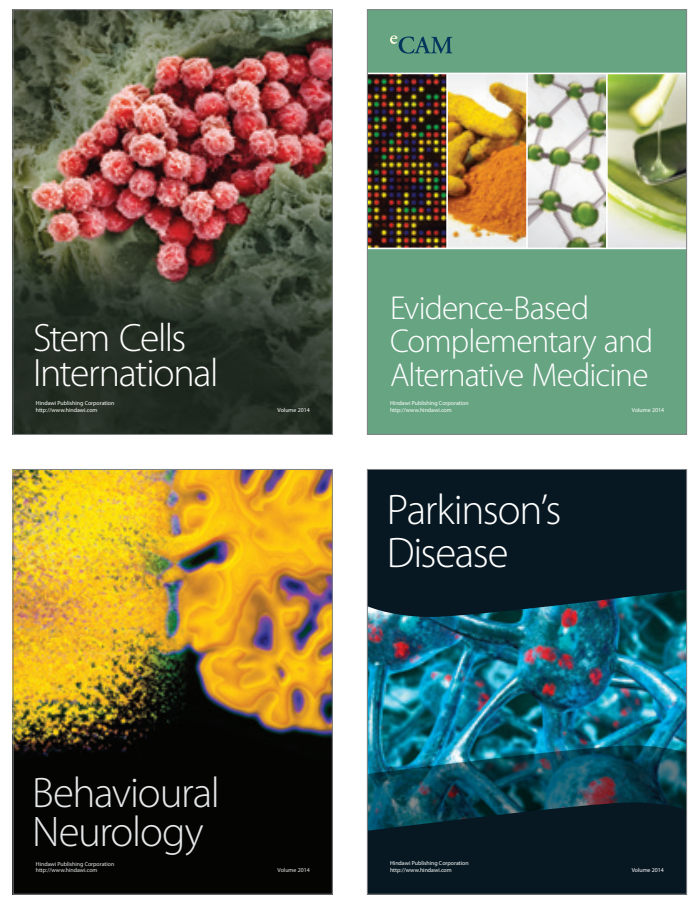
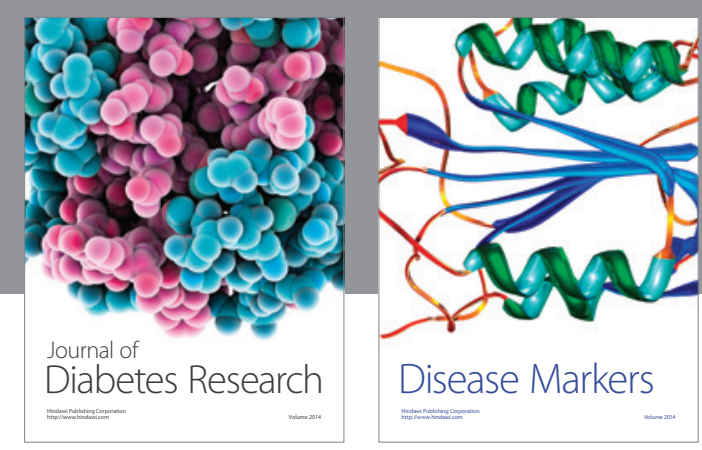

Disease Markers
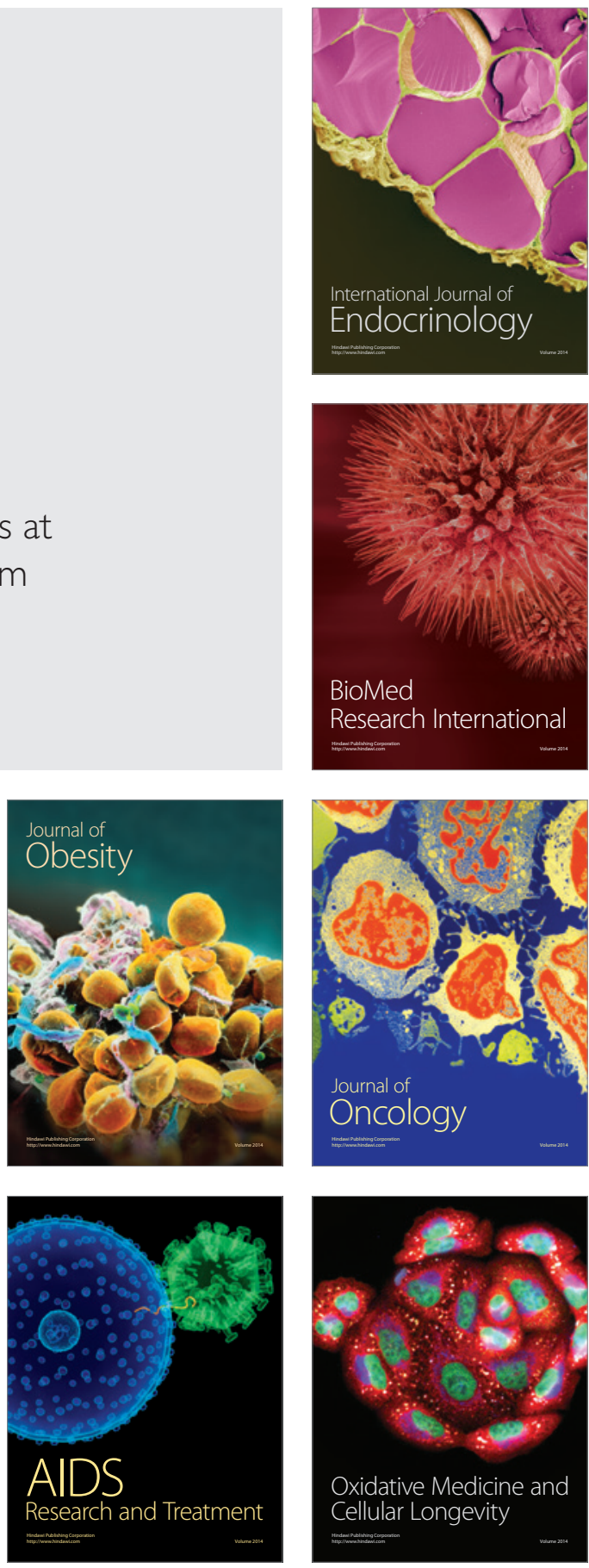